\author{
Paweł GRATA, PhD, Professor of the University of Rzeszów \\ Faculty of Sociology and History, University of Rzeszów \\ e-mail: pgrata@wp.pl \\ ORCID: 0000-0003-2358-3475
}

DOI: $10.15290 /$ oes.2018.04.94.13

\title{
STALINISM VERSUS CAPITALISM. INSTITUTIONAL CHANGES IN THE POLISH SOCIAL POLICY IN THE YEARS 1918-1956
}

\begin{abstract}
Summary
Goal - the aim of the paper is to present the fundamental institutional changes which took place in the Polish social policy between 1918 and 1956, i.e. from regaining independence to the end of the Stalinist period in Poland. Therefore, the paper will present both the processes that constitute the construction of the social policy system, embedded in the European tradition and capitalist economy, and the process of dismantling of that system carried out by the communists at the end of the 1940s and at the beginning of the next decade, which imitated the Stalinist model of social activity of the state.

Research methodology - the paper has been prepared with the use of a number of research methods in the field of humanities and social studies, necessary for the proper reconstruction of institutional changes which took place in the Polish social policy in the discussed period. The research has been based on the query of the archival sources, printed and legal, as well as specialist press and research papers.

Score - the construction of the social policy system, which began in 1918, was not completed in the interwar period, but strong institutional foundations for such a system were created. After the World War II its reconstruction was, understandably, based on the pre-war rules. Political and systemic changes, which took place in Poland after communists gained full power, meant even greater nonuniformity between the institutional solutions, which stemmed from capitalism, and the model of socialism built in the late 1940s. Along with this process, social policy also underwent salinization and, as the result of institutional changes at the beginning of the 1950s, it had completely different functions than in the capitalist economy. It was objectified and it became an instrument of economic policy aimed at socialist industrialization and collectivization of villages. Its main task was no longer to solve social issues but to meet social needs. This new role, resulting from the Stalinist system, meant significant impoverishment of social policy and limiting the effectiveness of the state activity on social life.
\end{abstract}

Key words: social policy, capitalism, social issues, Stalinism

JEL classification: N3, N34 


\section{Introduction}

According to D.C. North, the Nobel prize winner in economics, institutions constitute the set game rules in the society and the restrictions that shape the political, economic and social interactions. Inherently, institutions in economy perform the functions of reducing the transaction costs and ought to be the instrument that is used by individuals in order to maximize the benefits aiming at increasing individual prosperity [North, 1990]. Such role perfectly suits the needs of social policy that for more than one hundred years has been an inseparable part of economic life of modern societies. It is the activity of the state, other public authorities as well as social entities that is aimed at neutralizing the inequalities resulting from the economic development of social issues. Its ultimate purpose is the increase of the aforementioned "individual welfare", whereas the particularly important measure serving the achievement of this objective are the rules of game, i.e. institutions [Auleytner, 2002, pp. 34-41].

At the turn of the $19^{\text {th }}$ and $20^{\text {th }}$ century social policy (as the result of the involvement of public authorities in economic existence) became the inseparable part of the capitalist system and over time it was considered as the element that reinforces and stabilizes the system. The presence of social policy in the capitalist system, which seemed to be natural at the beginning of the $20^{\text {th }}$ century, meant the adoption and development of this institution in the Polish state reconstructed after the World War I. In fact, after the end of the World War II, when communists took control of Poland, the situation changed dramatically. Along with the consolidation of both the communist authorities in Poland and the influence of the Soviet Union in the Central Europe the capitalist system was gradually replaced by the Stalin's system that was based on the nationalization and centralization of authority, planning and the aspiration to adopt the Soviet solutions (that were considered as a role model). Within its frameworks the position of the social policy was entirely different, which clearly meant not only breaking up with the dominating institutional tradition in this aspect, but also the creation of new frames and rules that would guarantee the realization of entirely different tasks of social policy than in capitalism.

The aim of this paper is to show the major institutional changes that take place in Polish social policy with regards to the period between the regaining of independence to the end of the Stalin period in Poland. There will be presented both the processes that contribute to the construction of the social policy system that would be Polish, rooted in the European tradition and combined with the capitalist economy and targeted at following the Stalin's model of the social activity of the state, whereas its disassembly was conducted by communists in the late 1940s and at the beginning of the subsequent decade. 


\section{The creation of the institution of Polish social policy in the conditions of the capitalist system}

When Poland regained independence, political leaders faced a number of challenges that included the essential issues connected with the fusion and unification of the state's social activity rules that were in force in three empires. The problem was particularly difficult in the situation where territorial differences were so large that in principle the social position of population in particular empires was entirely different, just as the conditions of running economic activity. It should be noted that a complete system of social insurances existed only in the German empire (in the conditions existing then when the insurance included diseases, accidents at work, getting old and disability), whereas in the Russian empire such insurances were completely unknown. On the one hand, it implied a completely worse position of the workers employed in the empires other than German, but on the other hand the production costs of employers from the Russian empire were lower. There were also considerable differences in other spheres of social policy, which in the process of constructing its own system placed territorial unification (not simple) in the first place in combination with the establishment of institutions (previously unknown in some areas) in the entire country [Grata, 2013a, pp. 12-14].

Post-war social atmosphere and left-wing provenance of the first central government led by J. Moraczewski decided upon a relatively fast rate of introducing in Poland modern workers' rights connected with preserving jobs. The eight-hour day and 46-hour work week, the establishment of Labor Inspection, the principles regarding the functioning of trade unions, collective agreements in farming, later on holiday allowances as well as the protection of work performed by youth and women introduced in the middle of 1924 created the institutional frameworks of this classical sphere of social policy closely connected with the shaping and evolution of the capitalist system [10 lat..., 1928, pp. 11-17].

In other spheres the situation was more difficult. As regards social insurances already in the years 1919-1920 there was success connected with the adoption of the regulations concerning insurance in case of diseases and for employed workers in the entire country, but further actions were much more complicated. In 1924 compulsory accident insurances were offered for workers in the former Russian empire who previously were deprived of such benefit, whereas in 1927 President issued the regulation that regulated the issues concerning the insurance of whitecollar workers. However, there were still ongoing works on the so-called integration of the insurance system, the inseparable element of which would be the insurance in case of getting old and connected with the disability of workers in the former Russian and Austrian empires. They became successful when the so-called integration act from 28 March 1933, as the consequence of which only in January of the subsequent years (i.e. 15 years after independence was regained) it was possible to assume that the institutional frameworks of the social insurance system were complete [Chylak, 2017]. 
The establishment of the institution responsible for the employment policy can be assessed in positive terms. In the middle of 1924, as one of the first countries worldwide, Poland introduced the unemployment insurance (financed from the budget), whereas during the Great Depression (thanks to the formation of the Labor Fund in 1933) there was formed a comprehensive and modern system of active support for unemployed people. The system was supplemented on an ad hoc basis by the so-called winter assistance, which was to a large degree organized by the state [Act 1924, 67/650; Act 1933, 22/163].

The institutional background was considerably worse as regards two spheres of social policy that in principle had to complement the system of social insurances. In the situations leading to the loss of income necessary for existence people gained support from social welfare institutions, whereas the so-called public health service (not connected with the insurance in case of diseases) was supposed to take care of their health. Theoretically, one may assume that the institutional frameworks of two domains were created relatively fast because already in 1919 there was adopted the so-called fundamental sanitary act which comprised the medicinal issues, whereas in 1923, after several years of interval, Seym passed the act on social welfare [Decree 1919, 15/207; Act 1923, 92/726].

However, the problem was connected with the fact that both legal acts had framework character and in fact did not create the basis for the creation of efficient institutions of public health and social care. Its best confirmation was the fact that the second act did not come into force in the former German empire, where system of social welfare institutions of German provenance was still developed and verified. The construction of the institution of public health service appeared to be in a slightly better situation. The regulation on medical institutions from 1928 did not include the areas of former Galicia, while the real chance for creating a consistent system (comprising the uninsured part of the population) became the act on public health service that was adopted in June 1939 [Grata, 2013a, pp. 21-23].

To sum up, the construction of the own social policy system that initiated in Poland in 1918 was not completed in the inter-war period, but the institutional bases of such system were created. It is worth emphasizing that even in places where the system of institutions was constructed to the degree adequate for the needs, their efficiency was considerably limited as the consequence of the underdevelopment of the state and its social and occupational structure. Social insurances comprised only a dozen percent inhabitants, the active employment policy and public works could not reduce the overt and hidden unemployment (estimated as affecting a few million people), as regards work protection there was problem connected with noncompliance with the existing regulations and limitation of workers' powers during the Great Depression. The reality of the functioning of still imperfect health service and social welfare institutions was particularly difficult. In the first case it meant that the vast majority of the country's inhabitants remained without the access to of the still rudimentary system (estimated at the level of $75 \%$ ), whereas in the second case there were dramatic differences in the access to social assistance that was financed from public funds and organized by self-government authorities and was functio- 
ning relatively well in big cities, while in rural areas (especially those most underdeveloped) of Eastern it almost did not exist [Grata, 2013, pp. 296-299].

\section{Post-war system reconstruction - the "improvement" of capitalism}

After the end of the World War II the reconstruction of the system took place on the basis of the pre-war rules, which is an understandable fact. However, new authorities (led by the communists) quickly undertook activities that despite preserving old institutions, aimed at improving them at certain degree. On the one hand, in the context of still ongoing struggle to gain control it was targeted at winning social support, but on the other hand (as it became evident but was still not announced) it was necessary to prepare the basis for major systemic changes in social policy that were supposed to occur a few years afterwards.

In the first period the activities undertaken at the legislation level aimed at introducing regulations that were beneficial for employees and brought back the benefits previously reduced owing to the Great Depression (leaves, remuneration for the overtime work, restoring of a self-government in insurance institutions). Additional activities included the introduction of new solutions such as staff committees, the increasing importance of trade unions or the establishment of the Vacation Fund (Fundusz Wakacji Pracowniczych) offering vacations for groups of workers [Protokoty..., 1945, pp. 474-478; Decree 1945, 21/117, 43/236, 43/238; Decree 1946, 51/285; Chumiński, 1999, pp. 142-171].

From the perspective of the redefinition of institutional solutions in social policy much more interesting issue appeared to be the transformations of the present executive structures that began already in the first months after liberation. The first decision of this type was the liquidation of the Main Caretaking Council (Rada Główna Opiekuńcza) from the occupation times which in December 1944 was replaced by the Central Committee of Social Welfare (Centralny Komitet Opieki Społecznej) closely governed by the authorities. It was supposed to take over the present local structures of the Main Caretaking Council and dominate the caretaking activity in the country. Although this situation did not take place owing to fast re construction of the charity activities of the Church, it was an important signal of the planned institutional changes connected with social welfare [Rozporzadzenia..., 1944, p. 6; Kłapeć, 2011, pp. 274-289; Miernik, 2010, pp. 189-190].

It is difficult to minimize the role of the modifications introduced in the first months of 1945 at the levels related to the management of the social policy. In April the ministry of health was isolated from the Ministry of Labor, Social Welfare and Health which soon became the outpost of systemic changes in organizing social life. In June the decision was made to make the Ministry of Education that was responsible for the issues connected with care of children and youth aged 3-18. In accordance with the official documents it aimed at correlating better the caretaking processes with the upbringing ones, while from the perspective of practice this meant fast reconstruction of state caretaking institutions where over time the 
indoctrinating activity was supposed to replace the caretaking activities and develop at large scale [Grata, 2017a, pp. 103-104].

The decisions made in the sphere of the employment policy appeared to be particularly essential and constituted the confirmation of the adopted direction of institutional changes in the social policy. In this aspect there was observed a trend connected with the centralization and nationalization of institutions combined with the major withdrawal from the rules established before the war. Above all, the basic institution responsible for the employment policy, i.e. Labor Fund, was liquidated due to its non-adjustment to the new reality. Secondly, labor exchange became the responsibility of national employment offices that gained monopoly on this type of an activity [Grata, 2017a, p. 102].

Both in the context of the still binding legal regulations and the essence of social insurance system the decision made in February 1945 concerning the removal of unemployment benefits from the instruments of the employment policy was astonishing. These benefits (universally considered as real achievements on the path to reconstructing employment entitlements in the capitalist system) were already rejected after the liberation and were considered as harmful from the perspective of realizing the strategic aim, i.e. full employment. Meanwhile there occurred a bizarre situation - employers paid fees for the insurances of employees against unemployment which were in principle allocated for the payment of benefits that the unemployed did not receive [Protokoly..., 1945, pp. 51-52].

The most precise touchstone of institutional changes initiated in Polish social policy after the war was the outcome of works on the act on public health service. In accordance with universal views the act was supposed to be the major breakthrough in the organization of health service in the country and its aim was to guarantee full unconditional access to it for all the citizens. Although there was no uniform view in terms of the organizational forms of the entitlement formulated in this manner, the essence of the assumption was undisputable. It was relatively quickly assumed that for economic reasons and owing to inadequate human resources public health service ought not to be completely free in the first stage, but from the systemic point of view it did not change the situation particularly. Meanwhile along with the political and economic changes the idea of public health service began to evolve and already at the end of 1947 it was replaced by social health service which was still based on the principle of central command. Importantly, the announcements of such transformations appeared in the public announcements of the representatives of the Ministry of Health from the second half of the year 1945, owing to which this particular level of state's social activity may be considered as the one that at the concept level quickly adopts new directions connected with the Soviet system [Grata, 2017, pp. 6-12].

From the perspective of the political processes taking place in Poland attention needs to be drawn to the elements of social support that were introduced in the first period after liberation in relation to the individuals who had special merits for the so-called power of the people. Attention needs to be drawn especially to the benefits addressed at individuals survived after the death of the participants of the guerilla 
movement. Initially this instrument was not political and was addressed at people who suffered as the consequence of combats with the occupier, but over time this institution was directly focused on supporting the only right trend in the guerilla movement connected with the communists. What is more, the families of guerillas considered as wrong were gradually deprived of the previously offered privileges [Act 1945, 30/180; Decree 1945, 34/202, 51/294; Decree 1947, 5/22; Decree 1948, 21/139; Decree 1949, 55/434, 55/435; Zwolińska, 1949, p. 171].

While summarizing the first years after the war (when social policy was still dominated by the pre-war institutional solutions) attention ought to be drawn to the noticeable aspiration to reconstruct them. At the beginning the aspiration was rather concealed, was almost "timid", but with the time passing by it became more and more noticeable, which was the effect of the fact that the communists with their allies took all the executive powers and there was the sign of entirely new times that were yet to come.

\section{4. "Stalinism is invincible", i.e. the disassembly of capitalist institutions}

The year 1948 became both the breakthrough and the starting point of almost entire disassembly of the traditional "capitalist" institutions of social policy similarly to other spheres of public life. The symbol of this breakthrough were the ultimate solutions regarding the regulation of the principles of the functioning of the health service system included in the act on social institutions of health service and command economy in health service from 28 October 1948. In accordance with its bequests, the health service system was supposed to be based on central planning, uniform board of the Ministry of Health, the socialization of health service entities, the work obligation of doctors in social health service institutions and in extreme cases there was possibility of compulsory relocations of doctors into deficit areas from the point of view of their accessibility [Act 1948, 55/434].

During the realization of these plans within the subsequent several years there were observed major institutional changes in health service. Hospitals were nationalized, the Ministry of Health took over the insurance health service, whereas in relation to doctors the obligation to work was introduced and their job lost the status of a free profession. The element of these changes was also the politicization and ideologization of education in medical professions as well as ostentatious withdrawal from the idea of public health service in combination with the typical division of societies into classes as regards the access to medical services - so typical for Stalin's system. From that moment on such unconditional access will be possible for those employed in socialized sector, whereas the realization of traditionally ignored countryside requirements was directly dependent on the advancements of collectivization [Grata, 2017, pp. 14-19].

Simultaneously with changes in the health service system there were introduced interconnected reforms of social insurance institutions. While in 1948 their system was complemented by the family insurance that was positive for the beneficiaries, 
later on the direction of changes was unambiguous. They were initiated by the unification of mostly separate insurance funds that took place in 1949, whereas one year later the medical activities became the responsibility of the Medical Institution for Employers (Zakład Lecznictwa Pracowniczego) connected with the Ministry of Health and social insurance institutions that traditionally organize the current functioning of the system. The confirmation of the almost collision-free introduction of Stalin's ideas in the institutional solutions was the inclusion of the financial insurance system into the state budget. The "adjustment" changes came to an end as the result of the decree from 2 February 1955 that liquidated The Polish Social Insurance Institution (ZUS) and (similarly to the Soviet Union) and made trade unions responsible for conducting insurances since they have large impact on workers and constitute an essential transmission path of the Communist party [Decree 1947, 66/414; Act 1949, 18/109; Act 1950, 36/333; Decree 1955, 16/31; Balcerski, 1947, pp. 1-6].

The process of institutional changes in other spheres of social policy was similar. Importantly, they implied not only the withdrawal from the traditional "bourgeois" solutions looking as if they were taken from the enemy, but also the genuine worsening of the way of preventing critical situations of individuals and social groups. The new Stalin's version of the social policy along with the group of interrelated institutions became one of the components of the system targeted at the realization of political and economic objectives, whereas in the social sphere it aimed at preventing and minimizing the effects of social issues as well as supporting the industrialization and collectivist processes in combination with the euphemistically considered "satisfaction of social needs" by increasingly more centralized and oppressive state which is also paternalistic.

All the aforementioned elements were particularly visible in the changes taking place within the frameworks of the institutions creating labor protection which is the basis of social activity of the state. The basic institutional changes included the marginalization of work inspection (that takes care of the workers' rights) and making it subordinated to national councils, the attempt to replace it by the social work inspection following the Soviet model, the liquidation of labor courts which became "redundant" in the new conditions. The confirmation of these changes was the ruthless reduction of employment benefits, the aim of which was to support the process of socialist industrialization. They meant considerable worsening of the position of employed women for whom the authorities enabled access to many professions that were forbidden for health reasons in the capitalist Poland that was considered as the mainstay of social backwardness; additionally women were allowed to work at night. What is more, the regulations from 2 August 1951 in fact reduced the age of children allowed to work from 15 to 14 years old, i.e. the hiatus introduced for the first time during the war by Hitler's occupiers... [Act 1950, 6/52; Decree 1951, 41/311; Jarosz, 2000, pp. 230-231; Kołodziejczyk, 2003, pp. 162-163; Puławski, 1951, pp. 56-59; Rusinowa, 1951, p. 36].

The aspiration to satisfy the increasing demand for labor force was closely connected also with the activities undertaken in that period within the frameworks 
of the employment policy and with the involvement of social welfare in the realization of this objective. In the first case what was particularly characteristic was the occupational animation of the previously unemployed people and the involvement of disabled people as well as mass recruitment of the labor force that is necessary in the period of accelerated industrialization and follows the Soviet patterns. Simultaneously, the employment offices were no longer the institutions that supported unemployed individuals in their job search and became the institutions that guarantee proper "supplies" of employees for the national business company [Akcja..., 1947-1950, pp. 58-60; Werbunek..., 1950, p. 4; Grata, 2016, pp. 25-26].

The basic purpose of social care became the productiveness of proteges who were supposed to receive versatile support in their path to professional activity. The protective activity was meant to be reduced solely to the individuals that were entirely incapable of working, while this process was essential in the context of the realized liquidation of non-state care facilities that in principle results in the reduction of their accessibility. As regards taking care of children an important element of the changes taking place was the intensified (since 1948) ideologization of up-bringing in state institutions of closed and open caring Jarosz, 1998, pp. 114-138; Lopato, 1991, pp. 150-152; Oleszczyńska, 1980, p. 117; Rusinek, 1950, pp. 14-17].

\section{Conclusions}

The political and systemic transformations taking place in Poland after communists gained the full executive powers meant that the institutional solutions stemming from capitalism did not correspond to Stalin's model of socialism created in the late 1940s. Simultaneously with this process Stalin model was applied also to the social policy, which owing to the introduced institutional changes in the early 1950s performed completely different functions than in capitalist economy. It was objectified and became the instrument addressed at the socialist industrialization and rural collectivization in the authorities' economic policy and its basic task was not only the solving of social issues but to satisfy social needs. Importantly, the new role resulting from the Stalin system implied considerable depletion of the social policy and reduction of the efficiency of the impact that this sphere of state activity has on social life.

\section{References}

10 lat polityki społecznej państwa polskiego 1918-1928, 1928, Ministerstwo Pracy i Opieki Społecznej, Warszawa.

Act on 16 August 1923 on social welfare, Journal of Laws 1923, no. 92, item 726. Act on 16 March 1933 on Labor Fund, Journal of Laws 1933, no. 22, item 163. Act on 18 July 1924 on insurance against unemployment, Journal of Laws 1924, no. 67 , item 650 . 
Act of 28 October 1948 on social health care institutions and command economy in health service, Journal of Laws 1948, no. 55, item 434.

Act on 1 March 1949 on the modification of selected regulations concerning social insurance, Journal of Laws 1949, no. 18, item 109.

Act of 4 February 1950 on Social Labor Inspection, Journal of Laws 1950, no. 6, item 52.

Act on 20 July 1950 on the Polish Social Insurance System, Journal of Laws 1950, no. 36, item 333 .

Act on 23 July 1945 on benefits and assistance for individuals who had been the participants of the underground and guerilla movements but died in their combat to rescue Poland from Hitler army, Journal of Laws 1945, no. 30, item 180.

Akcja gospodarczego usamodzielnienia kobiet trw. Akcja AZ w latach 1947-1950. Normatywy, sprawozdania, protokót, korespondencja 1947-1950, Archiwum Akt Nowych, Ministerstwo Pracy i Opieki Społecznej 1945-1960, sygn. 561.

Auleytner J., 2002, Polityka społeczna czyli ujarzmianie ładu socjalnego, WSP TWP, Warszawa.

Balcerski S., 1947, Nowe ubezpieczenie rodżinne, „Przegląd Ubezpieczeń Społecznych”, no. 9.

Chumiński J., 1999, Ruch zawodowy w Polsce w warunkach kształtujacego sie systemu totalitarnego 1944-1956, Wydawnictwo Akademii Ekonomicznej im. Oskara Langego we Wrocławiu, Wrocław.

Chylak K., 2017, Ubezpieczenia spoteczne i zaopatrzenia emerytalne w II Rzeczypospolitej, Wydawnictwo Polskie IHOO, Warszawa.

Decree of 8 February 1919 Basic sanitary law, Journal of Laws 1919, no. 15, item 207.

Decree of 16 May 1945 on the modification of art. 16 of the act of 18 December 1919 on the work duration in industry and trade, Journal of Laws 1945, no. 21, item 117.

Decree of 18 July 1945 on the assistance and benefits for the families of Polish Army soldiers and discharged soldiers, Journal of Laws 1945, no. 34, item 202.

Decree of 29 September 1945 on the modification of the act of 2 July 1924 on the work of youth and women, Journal of Laws 1945, no. 43, item 236.

Decree of 29 September 1945 on the modification of the act of 16 May 1922 on leaves for the workers employed in industry and trade, Journal of Laws 1945, no. 43 , item 238.

Decree of 13 November 1945 on benefits and assistance for widows and orphans of the victims of the enemies of the democratic system of Poland, Journal of Laws 1945, no. 51, item 294.

Decree of 19 September 1946 on the modification of the act on working time in industry and trade, Journal of Laws 1946, no. 51, item 285.

Decree of 3 January 1947 on the modification of the decree on benefits and assistance for widows and orphans of the victims of the enemies of the democratic system of Poland, Journal of Laws 1947, no. 5, item 22. 
Decree of 14 April 1948 on benefits and assistance for the Polish Army soldiers, soldiers and officers of public services, the members of the Voluntary Reserves of Ctizen's Police - and their families, Journal of Laws 1948, no. 21, item 139.

Decree of 28 October 1947 on family insurance, Journal of Laws 1947, no. 66, item 414.

Decree of 26 October 1949 on the modification of the act of 23 July 1945 on benefits and assistance for individuals who had been the participants of the underground and guerilla movements but died in their combat to rescue Poland from Hitler army, Journal of Laws 1949, no. 55, item 434.

Decree of 26 October 1949 on the modification of the decree of 13 November 1945 on benefits and assistance for the victims of the enemies of the democratic system of Poland, Journal of Laws 1949, no. 55, item 435.

Decree of 2 August 1951 on labor and occupational training of youth in places of employment, Journal of Laws 1951, no. 41, item 311.

Decree of 2 February 1955 on submitting social insurances to trade unions, Journal of Laws 1955, no. 6, item 31.

Grata P., 2013, Polityka spoteczna Drugiej Rzecrypospolitej. Uwarunkowania - instytugje działania, Wydawnictwo Uniwersytetu Rzeszowskiego, Rzeszów.

Grata P., 2013a, Procesy unifikacyjne w polskiej polityce spolecznej w latach 1918-1939, [w:] Od kwestii robotniczej do nowoczesnej kwestii socjalnej. Studia z polskiej polityki spotecznej XX $i$ XXI wieku, Grata P. (red.), t. I, Wydawnictwo Uniwersytetu Rzeszowskiego, Rzeszów.

Grata P., 2016, Obciażenia systemowe w polskiej polityce spotecznej w latach 1944-1950, [w:] Krajowe $i$ miedsynarodowe konteksty polityki spotecznej, Auleytner J. (ed.), Dom Wydawniczy Elipsa, Warszawa.

Grata P., 2017, Od Drugiej Rzecsypospolitej do Polski Ludowej. Ewolucja systemu ochrony zdrowia w Polsce w latach 1944-1950, „Polska 1944/45-1989. Studia i Materiały”, nr 15, DOI: http://dx.doi.org/10.12775/Polska.2017.01.

Grata P., 2017a, Odbudowa polskiej polityki spotecznej w okresie istnienia Rzqdu Tymcrasowego (styczeńn-czerviec 1945), „UR Journal of Humanities and Social Sciences” nr 4(5), DOI: 10.15584/johass.2017.4.4.

Jarosz D., 1998, Główne kierunki džiałalności państwa w zakresie stalinizacji uychowania w Polsce w latach 1948-1956, „Mazowieckie Studia Humanistyczne”, nr 2.

Jarosz D., 2000, Kobiety a praca zawodowa w Polsce w latach 1944-1956 (glówne problemy w świetle nonych badań śródtowych), [w:] Kobiety a praca. Wiek XIX i XX, Żarnowska A., Szwarc A. (red.), Wydawnictwo DiG, Warszawa.

Kłapeć J., 2011, Rada Gtónna Opiekuńcza w dystrykcie lubelskim w latach 1940-1944, Wydawnictwo UMCS, Lublin.

Kołodziejczyk E., 2003, Inspekcia Pracy w Polsce 1919-1999, Wydawnictwo KOLPRESS, Warszawa.

Lopato J., 1991, Pomoc spoteczna wobec potrzéb ludzi starych na wsi, Ośrodek Badań Społecznych, Warszawa.

Miernik I., 2010, Centralny Komitet Opieki Spotecrnej 1945-1949. Powstanie i gtónne etapy działalności, [w:] Dobrocsynność i pomoc spoteczna na ziemiach polskich w XIX, XX i na 
poczqtku XXI wieku, Przeniosło M. i M. (red.), t. 2, Kieleckie Towarzystwo Naukowe, Kielce.

North D.C., 1990, Institutions. Institutional Change, and Economic Performance, Cambridge University Press, Cambridge.

Oleszczyńska A., 1980, Opieka społeczna w Polsce w okresie 60-lecia, [w:] Rodowód, rozwój i perspek.tywy polityki społecznej w Polsce, Sieńko I. (red.), COMSNP, Warszawa.

Państwowa zasadnicza ustawa sanitarna, 1919, „Dziennik Praw Państwa Polskiego”, nr 15, item 207.

Protokoly posiedzeń rzadu I-VI 1945, Archiwum Akt Nowych, Urząd Rady Ministrów [1944-1952] 1953-1996 (URM), mkf. 23154.

Puławski Z., 1951, Rozszerzenie zakresu pracy kobiet, „Praca i Opieka Społeczna”, nr 2.

Rozporzadzenia, zarzadzenia, okólniki kierownika Resortu Pracy, Opieki Spotecznej i Zdrowia 1944, Archiwum Akt Nowych, Polski Komitet Wyzwolenia Narodowego, sygn. $\mathrm{XI} / 1$.

Rusinek K., 1950, Zagadnienia pracy i pomocy społecznej w driałalności Rad Narodonych, „Praca i Opieka Społeczna”, nr 1-2.

Rusinowa A., 1951, Nowe zatożenia szkolenia zawodowego i ochrony pracy mtodocianych, „Przegląd Zagadnień Socjalnych”, nr 2.

Werbunek pracownikón do przemystu i rolnictwa. Zestawienia statystyczne 1950, Archiwum Akt Nowych, Ministerstwo Pracy i Opieki Społecznej 1945-1960, sygn. 572.

Zwolińska H., 1949, Zasitki i pomoc dla rodżin po poleglych uczestnikach ruchu podriemnego i partyzanckiego, „Praca i Opieka Społeczna”, nr 3-4. 